\title{
IF ONLY ...
}

\section{A taste of your own medicine.}

\section{BY TONY BALLANTYNE}

"D octor," said Sacha, "Can you give me your assurance that this injection won't harm my children?"

"Well, there's always some risk, Ms Melham. I do have a leaflet that explains everything..."

Sacha placed a finger on the table.

"I don't need a leaflet, Doctor. I simply want your assurance that this injection will cause Willow and Gregory no harm ..."

Doctor James Ferriday gazed at the finger.

"As I said, there is always a small risk, but if you look, you will see that this is less than the probability of..."

Sacha held up her hand.

"Please, Doctor. Don't try and confuse the issue."

"I'm not trying to confuse the issue, I'm simply presenting you with the facts..."

Sacha rose to her feet.

"Well, I think I've heard enough. Willow, Gregory, put your coats back on. Thank you, Doctor, we'll be ... what's that?"

James's screen flashed red and green.

"Oh dear," he said, reading the yellow writing scrolling across the monitor. "I think you should take a seat."

Sacha did so. Her son slipped his hand into hers.

"What's the matter, mummy?"

"Nothing, dear. Is everything OK, Doctor?"

"I'm sorry, Ms Melham ..." he began, and then more kindly. "I'm sorry, Sacha, but you've crossed the threshold. I'm afraid to say, you're not allowed science any more."

"I'm what?"

"You're not allowed science any more," repeated James.

Sacha's lips moved as she tried to process what he had said.

"You're saying that you're refusing my children treatment?"

"No," said James. "Quite the opposite. You and your children will always be entitled to the best medical care. It's just that you, Sacha, no longer have a say in it. I shall administer the vaccination immediately."

"What?" Sacha sat up, eyes burning with indignation. "How dare you? I, and my husband, are the only ones who say how my family is run."

"Well, yes," said James. "But you no longer have a say in things where science is involved. You're not allowed science any more."

"I never heard anything so ridiculous! Who decided that?"
"The Universe."

"The Universe? Why should the Universe say I'm not allowed science any more?"

"Because you haven't paid science enough attention. You've had the opportunity to read the facts and the education to be able to analyse them, yet you have consistently chosen not to."

"The education?" exclaimed Sacha. "Hah! My science education was terrible. None of my teachers could explain anything properly."

"Really?" said James. "That would certainly be grounds for appeal..."

He pressed a couple of buttons. Tables of figures appeared on the screen.

"No," he said, shaking his head. "I'm sorry ... it turns out that your teachers were all really rather excellent. You went to a very good public school, after all. If you look at your teachers' results you will see they added significant value to their pupils' attainment."

Sacha pouted.

"Well, they didn't like me."

"Possibly..."

He pressed a couple more buttons.

"What?" said Sacha, hearing his sharp intake of breath.

"Look at this," said James, scrolling down a long table. "Times and dates of occasions when you've proudly admitted to not being good at maths."

"What's the matter with that? I'm not."

"It's not the lack of ability, Sacha, it's the fact that you're proud of it. You'd never be proud of being illiterate. Why do you think your innumeracy is a cause for celebration?"

"Because... Well..."

"That's why you're not allowed science any more."

"This is outrageous!" snarled Sacha. "How can this happen?"

"Oh, that's easy," said James. "Magic."

"Magic?" said Sacha, her eyes suddenly shining. "You mean there's really such a thing?"

"Of course not. But I can't explain to you how it's really done because you're not allowed $\rightarrow$ NATURE.COM

Follow Futures on

Facebook at:

go.nature.com/mtoodm science any more."

Sacha fumbled for her handbag.

"I'm calling the BBC," she said. "I'm a producer there, you know. I'll report you."

"Report me to who you like," said James. "The story will never get out. All your cameras and microphones and things work on science."

Sacha gazed at him.

"Who gave you the right to control my life?"

"You've got it the wrong way round. You gave the right to control your life away. You're the one who chose to ignore the way the world works."

"Hah!" said Sacha. "The way the world works! Bloody scientists. You think the world is all numbers and machines and levers. You don't understand anything about the soul or spirit."

"Of course I do," said James. "I've been happily married for 20 years. I have two children that I love. I play the piano, I enjoy reading. It's just that I have additional ways of looking at things."

Sacha stood up.

"Willow, Gregory. We're going home," she glared at James. "That is if I'm still allowed to drive? You don't have something against women drivers as well do you, Doctor?"

"This is nothing to do with you being female, Ms Melham," said James, calmly. "This is purely about your attitude to science. Now, before you go, I'll administer the injection to the three of you."

"You will not! I will not allow it."

"I told you, you have no choice."

"Why? Because I disagree with you?"

For this first time, James's anger showed itself.

"No!" he snapped. "You don't get it! You're allowed to disagree with me, I want you to disagree with me! I'd love to engage in reasoned debate with you. But until you take the trouble to understand what you're talking about, you're not allowed science any more. Now, roll up your sleeve."

Sacha muttered something under her breath.

"What's in the injection?" said James. "You know, you start asking questions like that, you might get science back..." -

Tony Ballantyne's latest collection of tales is Stories of the Northern Road (NewCon Press). You can find him at tonyballantyne. wordpress.com. 